\title{
Medically managed tubal ectopic pregnancy presenting as a peritoneal loose body
}

\author{
William Robert Cooke, ${ }^{1,2}$ Emma Kirk $^{3}$
}

${ }^{1}$ UCL EGA Institute for Women's Health, University College London, London, UK ${ }^{2}$ University College Hospital, London, UK

${ }^{3}$ North Middlesex University Hospital, London, UK

\section{Correspondence to} Dr William Robert Cooke, cooke.wr@gmail.com

Accepted 18 August 2015
CrossMark

To cite: Cooke WR, Kirk E. BMJ Case Rep Published online: [please include Day Month Year] doi:10.1136/ bcr-2015-211871

\section{DESCRIPTION}

Peritoneal loose bodies are asymptomatic free intraperitoneal masses, typically found incidentally. Their aetiology is attributed to torsion and separation of the appendices epiploicae; histology usually shows fibrous tissue. ${ }^{1}$ We report a case of ectopic pregnancy with a co-incidental finding of a peritoneal loose body at the time of laparoscopy.

A 30-year-old woman with a history of two previous ectopic pregnancies, both managed medically with methotrexate, presented with a positive pregnancy test and acute lower abdominal pain. A diagnosis of a right-sided ectopic pregnancy was made on transvaginal ultrasound. In view of her pain, she was treated surgically. Laparoscopy showed a $30 \times 20 \times 10 \mathrm{~mm}$ unattached cystic structure in the vesicouterine pouch (figure 1), in addition to a ruptured right ampullary ectopic pregnancy. Histologically, the cystic structure had degenerate decidua remnants at its core (figure 1).

The histology suggests that the peritoneal loose body represented one of the two previous ectopic pregnancies, which had been expelled (spontaneously or as a result of methotrexate) into the peritoneal cavity. This represents the first case of a peritoneal loose body arising from a previous medically managed ectopic pregnancy.

The peritoneal loose body may represent an early lithopaedion (an advanced abdominal pregnancy retained within the peritoneum, which has become calcified). ${ }^{2}$ Santoro et al hypothesise that abnormal fallopian contractions may lead to intraperitoneal expulsion of the embryo, resulting in lithopaedion. We propose that the peritoneal loose body described may similarly have arisen due to abnormal fallopian contractions and may have become calcified at a more advanced gestation.

\section{Learning points}

- This represents a new aetiology for peritoneal loose body, which has previously been thought to originate only from the separation of appendices epiploicae.

- The peritoneal loose body may represent an early lithopaedion (calcified extrauterine pregnancy).

- This case provides insight into the pathophysiology of tubal ectopic pregnancy.

Acknowledgements The authors would like to thank Rebecca Gillibrand for her assistance in obtaining and interpreting the light microscopy image.

Contributors WRC obtained the images, completed the literature search, and wrote and edited the manuscript. EK conceived the case report, gained patient consent and edited the manuscript.

Competing interests None declared.

Patient consent Obtained.

Provenance and peer review Not commissioned; externally pee reviewed.

\section{REFERENCES}

1 Kavanagh DO, Moran D, Flynn R, et al. Laparoscopic retrieval of a peritoneal mouse. Case Rep Med 2010;2010:pii: 624825.

2 Santoro G, Laganà AS, Sturlese E, et al. Developmental and clinical overview of lithopaidion. Gynecol Obstet Invest 2014;78:213-23.
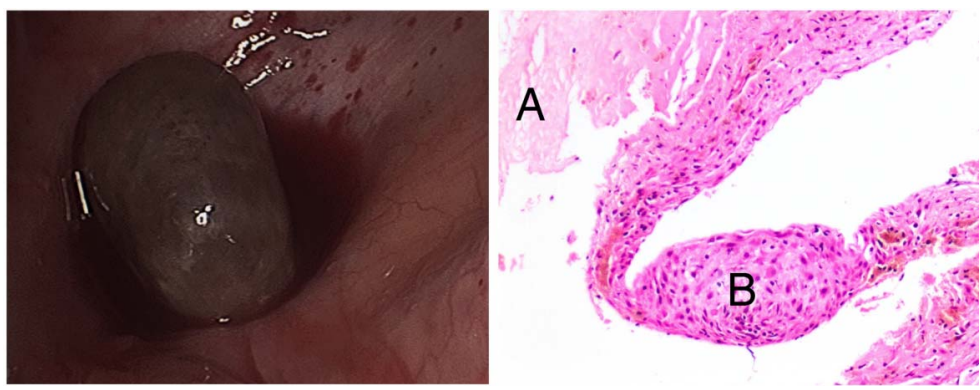

Figure 1 Left: laparoscopic image of $30 \times 20 \times 10 \mathrm{~mm}$ peritoneal loose body. Right: light microscopy image showing necrotic material $(A)$ and decidual remnants $(B)$. 
Copyright 2015 BMJ Publishing Group. All rights reserved. For permission to reuse any of this content visit http://group.bmj.com/group/rights-licensing/permissions.

BMJ Case Report Fellows may re-use this article for personal use and teaching without any further permission.

Become a Fellow of BMJ Case Reports today and you can:

- Submit as many cases as you like

- Enjoy fast sympathetic peer review and rapid publication of accepted articles

- Access all the published articles

- Re-use any of the published material for personal use and teaching without further permission

For information on Institutional Fellowships contact consortiasales@bmjgroup.com

Visit casereports.bmj.com for more articles like this and to become a Fellow 